\title{
Recent Advances in Recovery of Lycopene from Tomato Waste: A Potent Antioxidant with Endless Benefits
}

\author{
Valentina Noemi Madia ${ }^{1}$, Daniela De Vita ${ }^{2}$, Davide Ialongo ${ }^{1}{ }^{\mathbb{D}}$, Valeria Tudino ${ }^{1}$, Alessandro De Leo ${ }^{1}{ }^{\mathbb{D}}$, \\ Luigi Scipione ${ }^{1}{ }^{\oplus}$, Roberto Di Santo ${ }^{1} \mathbb{D}$, Roberta Costi ${ }^{1, *}$ and Antonella Messore ${ }^{1}$
}

1 Istituto Pasteur-Fondazione Cenci Bolognetti, Dipartimento di Chimica e Tecnologie del Farmaco, "Sapienza" Università di Roma, p.le Aldo Moro 5, I-00185 Rome, Italy; valentinanoemi.madia@gmail.com (V.N.M.); davide.ialongo@uniroma1.it (D.I.); valeria.tudino@uniroma1.it (V.T.); alessandro.deleo@uniroma1.it (A.D.L.); luigi.scipione@uniroma1.it (L.S.); roberto.disanto@uniroma1.it (R.D.S.); antonella.messore@uniroma1.it (A.M.)

2 Department of Environmental Biology, "Sapienza" University of Rome, p.le Aldo Moro 5, I-00185 Rome, Italy; daniela.devita@uniroma1.it

* Correspondence: roberta.costi@uniroma1.it; Tel.: +39-064969-3247

check for

updates

Citation: Madia, V.N.; De Vita, D.; Ialongo, D.; Tudino, V.; De Leo, A.; Scipione, L.; Di Santo, R.; Costi, R.; Messore, A. Recent Advances in Recovery of Lycopene from Tomato Waste: A Potent Antioxidant with Endless Benefits. Molecules 2021, 26, 4495. https://doi.org/10.3390/ molecules26154495

Academic Editor: Roberto Fabiani

Received: 24 June 2021

Accepted: 23 July 2021

Published: 26 July 2021

Publisher's Note: MDPI stays neutral with regard to jurisdictional claims in published maps and institutional affiliations.

Copyright: (c) 2021 by the authors. Licensee MDPI, Basel, Switzerland. This article is an open access article distributed under the terms and conditions of the Creative Commons Attribution (CC BY) license (https:// creativecommons.org/licenses/by/ $4.0 /)$.

\begin{abstract}
Growing attention to environmental protection leads food industries to adopt a model of "circular economy" applying safe and sustainable technologies to recover, recycle and valorize by-products. Therefore, by-products become raw material for other industries. Tomato processing industry produces significant amounts of by-products, consisting of skins and seeds. Tomato skin is very rich in lycopene, and from its seeds, high nutritional oil can be extracted. Alternative use of the two fractions not only could cut disposal costs but also allow one to extract bioactive compounds and an oil with a high nutritional value. This review focused on the recent advance in extraction of lycopene, whose beneficial effects on health are widely recognized.
\end{abstract}

Keywords: lycopene; carotenoids; food waste; nutraceuticals; supercritical fluid extraction; pulsed electric fields treatment; enzyme-assisted extraction; supercritical fluid extraction; ultrasonic-assisted extraction; microwave-assisted extraction

\section{Introduction}

One of the major drawbacks in the food life cycle is food waste, inevitably produced during all the stages of the manufacturing process. These phases include agricultural production, industrial processing and distribution. With the aim to reduce the impact on the environment and, at the same time, give wastes a second life, in the last decade, there has been growing interest in reusing and upgrading food by-products from the processing industry. Indeed, food waste and by-products are a good source of high-value components, such as proteins, polysaccharides, fibers, flavor compounds and phytochemicals, as nutritionally and pharmacologically functional ingredients [1].

To preserve the resources and minimize the high costs of waste disposal, the new trend consists in the waste recovery processing residues as potential sources of compounds with active properties (nutraceuticals and functional ingredients) [2].

Nutraceuticals and functional ingredients present in agro-industrial waste can be recovered using various techniques that have been successfully applied for recovery and reuse of waste from industrial tomato processing. Tomato is the fruit berry of Solanum lycopersicum L., belonging to Solanaceae family. It is a native species to South America, domesticated in Mexico and introduced as an ornamental plant into Europe where it was considered poisonous before it was considered useful as a vegetable [3]. In 2019, Italy was the main European producer followed by Spain and Portugal: more than 10 million tons of tomatoes produced in Europe were processed to produce peeled tomatoes and juices, among others [4]. Tomato processing generates high amounts of by-products that represent an environmental inconvenience for producers but at the same time a source 
of bioactive compounds [5]. According to the common processing, industries produce as tomato by-products (TBPs) peel, seeds or pomace which consists mainly of peel, seeds and a small amount of pulp and represents up to $5 \%$ of the whole tomato [6]. TBP is a source of valuable compounds: minerals, vitamins dietary fibers, proteins, polyphenols and carotenoids [7].

The latter are yellow, orange and red pigments present in many plants. From a chemical point of view, these compounds are water-insoluble, with a conjugated polyene chain. Most of the carotenoids are tetraterpenes, with a 40-carbon skeleton; carotenoids with a 45- or 50-carbon skeleton, the so-called higher carotenoids, are known [8]. Moreover, carotenoids with fewer than 40 carbons (apocarotenoids) are present in nature as a result of a degradation of $\mathrm{C} 40$ carotenoid precursors, such as lycopene and $\beta$-carotene [9]. Carotenoids can be divided into two groups: carotenes and xanthophylls. Carotenes, including $\beta$ carotene and lycopene, are hydrocarbons, whilst xanthophylls contain oxygen atoms and in some cases are present as fatty acid esters, glycosides, sulfates and protein complexes [8]. One of the main carotenoids recovered from tomato waste is lycopene, besides $\beta$-carotene and lutein [5]. Lycopene is an acyclic carotene, with 11 conjugated double bonds. Lycopene is a phytonutrient playing an important role in human health. Indeed, it has long been known for its several biological activities such as antioxidant [10], anti-inflammation [11], hypoglycemic [12,13], photoprotection [14], anti-angiogenesis [15], anti-parasitic [16-19], antiviral [20] and others. Several studies have also indicated the effect of dietary lycopene in reducing the risk of chronic diseases such as coronary heart disease [21], being also useful in reducing the oxidative stress in human immunodeficiency virus (HIV)-infected patients under antiretroviral therapy that have less total antioxidant capacity [22-24]. Moreover, lycopene ameliorates skin and bone diseases and hepatic, neural and reproductive disorders with a mechanism of action that has been investigated [10,25].

All-trans lycopene (Figure 1), the most thermodynamically stable form [26], is the predominant species in tomato; however, the double bonds can undergo isomerization producing mono- and poly-cis isomers by effect of light and/or heat [27]. Lycopene, like other carotenoids such as $\beta$-carotene, is sensitive to light, heat and oxygen, and it may easily undergo (trans-cis) isomerization, thus resulting in an array of mono- or poly-cis isomers [28]. Several studies have shown that heat treatments, longer than $1 \mathrm{~h}$, favored the trans-cis isomeric conversion of lycopene while light irradiation induced cis-isomer degradation over time in tomato products $[29,30]$. Worth of note is that lycopene-based food products are very dynamic systems: indeed, during food processing, the proportion of cisisomers increases, and retro-isomerization during storage of processed foods happens [31] because cis-isomers are more unstable when compared to trans-isomers. Actually, even if lycopene prevalently exists in nature in the all-trans form, it has been suggested that the bioavailability of cis-lycopene in foods is higher than that of all-trans lycopene: cis-isomers are better absorbed due to the greater solubility in mixed micelles which favor intestinal absorption; moreover, the content of cis-isomers of lycopene in body tissues is believed to also depend on transport, degradation and heat-induced isomerization within the mammalian tissue [32] promoting in vivo trans-to-cis lycopene isomerization [28,33]. Given the predominance of the all-trans form (that is also the most stable under a thermodynamic point of view), the need to avoid the trans-to-cis isomerization for incorporating lycopene into nutraceuticals or functional foods is evident.<smiles>CC(C)=CCC/C(C)=C/C=C/C(C)=C/C=C/C=C/C(C)=C/C=C/C=C(C)/C=C/C=C(\C)CCC=C(C)C</smiles>

all-trans lycopene

Figure 1. Structure of all-trans lycopene. 
The composition and structure of the food matrix also influence the bioavailability of lycopene: indeed, cooking or shredding can increase bioavailability due to physical destruction or a softening of the plant cell membranes and through the breakdown of lycopene-protein complexes [34].

To date, the demand for functional food, supplements and cosmetics containing lycopene is rapidly growing. In order to improve the recovery of lycopene from natural sources, especially from solid waste resulting from the industrial processing of tomato, several approaches are used.

Organic solvents are used in traditional processes (i.e., fractional distillation, steam distillation, solvent extraction) to extract bio-compounds, such as lycopene, from plant materials. However, the use of such solvents poses several drawbacks for both human health and environment safety. Indeed, organic solvents not only create environmentally hazardous problems, but also their residues remaining in the final products become a major safety concern. The current concern for safety in food products has raised interest in "green" extraction techniques as alternative methods to the conventional extraction processes. This review aims at summarizing the most recent advances in conventional and novel techniques suitable for extracting lycopene from TBPs (Table 1) by providing an updated account of the main progress in this field of research. These data could hopefully improve the awareness in reducing food waste as much as possible and increase the reuse of components from processing industry by-products.

Table 1. Extraction methods for recovering lycopene from TBPs: advantages and disadvantages.

\begin{tabular}{|c|c|c|c|c|}
\hline & Extraction Method & Main Features & Advantages & Disadvantages \\
\hline & $\begin{array}{l}\text { Classical organic } \\
\text { solvent extraction } \\
(\mathrm{COSE})\end{array}$ & $\begin{array}{l}\text { solubilization of the } \\
\text { components of interest } \\
\text { into organic solvent/s } \\
\text { added to the plant matrix }\end{array}$ & $\begin{array}{l}\text { - easily modifiable parameters } \\
\text { (i.e., ratio solvent/matrix, } \\
\text { temperature, extraction time) } \\
\text { - large production capacity } \\
\text { - easy continuous operation }\end{array}$ & $\begin{array}{l}\text { - long process time } \\
\text { - toxicity of solvents traces that } \\
\text { can remain } \\
\text { downstream purification } \\
\text { operations } \\
\text { - high environmental impact } \\
\text { - high health risks (i.e., use of } \\
\text { highly flammable and/or } \\
\text { toxic solvents) }\end{array}$ \\
\hline \multirow{3}{*}{$\begin{array}{l}\text { Pretreatments } \\
\text { before COSE }\end{array}$} & $\begin{array}{l}\text { Pulsed electric } \\
\text { fields treatment }\end{array}$ & $\begin{array}{l}\text { application of electric field } \\
\text { pulsing on plant matrices } \\
\text { that induces } \\
\text { electropermeabilization }\end{array}$ & $\begin{array}{l}\text { - } \text { high extraction yields } \\
\text { - no thermal effect } \\
\text { - low operation cost } \\
\text { - } \text { short process time } \\
\text { - no isomerization or degradation }\end{array}$ & $\begin{array}{l}\text { dependence on medium } \\
\text { composition (conductivity) } \\
\text { - high cost of the equipment }\end{array}$ \\
\hline & $\begin{array}{l}\text { Enzyme-assisted } \\
\text { extraction }\end{array}$ & $\begin{array}{l}\text { use of enzymes catalyzing } \\
\text { the hydrolytic cleavage of } \\
\text { structural components of } \\
\text { the cell wall of the } \\
\text { waste product }\end{array}$ & $\begin{array}{l}\text { - } \text { high extraction yields } \\
\text { - } \text { reduction in extraction time } \\
\text { - } \text { reduction in using } \\
\text { organic solvent } \\
\text { - } \text { high selectivity }\end{array}$ & $\begin{array}{l}\text { - high enzyme cost } \\
\text { - currently available enzymes } \\
\text { cannot hydrolyze cell } \\
\text { walls completely } \\
\text { - difficulty of enzyme recovery } \\
\text { - high dependence on pH, } \\
\text { temperature, metal ions, etc. }\end{array}$ \\
\hline & $\begin{array}{c}\text { Supercritical fluid } \\
\text { extraction }\end{array}$ & $\begin{array}{l}\text { use of supercritical fluids } \\
\text { as the extracting solvents } \\
\text { to separate component/s } \\
\text { from the matrix }\end{array}$ & $\begin{array}{l}\text { - } \quad \text { high purity } \\
\text { - low operating temperatures } \\
\text { (no thermal degradation) } \\
\text { - free of organic } \\
\text { - } \text { solvents' residues } \\
\text { - } \text { fast and high yield } \\
\text { high selectivity }\end{array}$ & $\begin{array}{l}\text { - } \quad \text { high power consumption } \\
\text { - } \text { very expensive and } \\
\text { - } \text { elemplex equipment } \\
\text { - } \\
\text { consistency and } \\
\text { reproducibility may vary in } \\
\text { continuous production }{ }^{1}\end{array}$ \\
\hline
\end{tabular}


Table 1. Cont.

\begin{tabular}{|c|c|c|c|}
\hline Extraction Method & Main Features & Advantages & Disadvantages \\
\hline $\begin{array}{l}\text { Ultrasonic-assisted } \\
\text { extraction }\end{array}$ & $\begin{array}{l}\text { the ultrasound waves } \\
\text { cause a mechanical impact, } \\
\text { allowing greater } \\
\text { penetration of the solvent } \\
\text { into the plant body } \\
\text { ("sponge effect") }\end{array}$ & $\begin{array}{l}\text { - } \text { eco-friendly method } \\
\text { - } \text { high efficiency } \\
\text { - low energy consumption } \\
\text { - } \text { low equipment cost } \\
\text { - } \text { reduction in extraction time } \\
\text { - harmless } \\
\text { - } \text { use of small amount of } \\
\text { organic solvents }\end{array}$ & $\begin{array}{l}\text { - } \text { scale-up not feasible } \\
\text { thermolabile compounds } \\
\text { - } \text { highly reactive free } \\
\text { radical generation } \\
\text { - low selectivity } \\
\text { - limited extraction volumes } \\
\text { - lack of uniformity in the } \\
\text { distribution of } \\
\text { ultrasound energy }\end{array}$ \\
\hline $\begin{array}{l}\text { Microwave-assisted } \\
\text { extraction }\end{array}$ & $\begin{array}{l}\text { microwaves heat solvents } \\
\text { that contain samples, } \\
\text { thereby partitioning } \\
\text { analytes from the matrix } \\
\text { into the solvent }\end{array}$ & $\begin{array}{l}\text { - } \quad \text { eco-friendly method } \\
\text { reduced use or no use of } \\
\text { organic solvents } \\
\text { - } \text { possibility to avoid } \\
\text { thermal degradation } \\
\text { - } \quad \text { short extraction times } \\
\text { - high extraction yields }\end{array}$ & $\begin{array}{l}\text { - difficult to scale up } \\
\text { - potential risk of explosion in } \\
\text { case of closed vessel } \\
\text { operating conditions } \\
\text { - limited extraction volume } \\
\text { - high costs of microwave set-up } \\
\text { - limited choice of the } \\
\text { extraction solvents }\end{array}$ \\
\hline $\begin{array}{l}\text { Microemulsion } \\
\text { technique }\end{array}$ & $\begin{array}{l}\text { formation of } \\
\text { thermodynamically stable } \\
\text { dispersion of two } \\
\text { immiscible liquids in the } \\
\text { presence of surfactants } \\
\text { (microemulsions) that } \\
\text { improve the solubilization } \\
\text { capacity of both liquids }\end{array}$ & $\begin{array}{l}\text { - } \text { high extraction yields } \\
\text { - } \text { ease and economical scale-up } \\
\text { - } \text { efficient at room temperature } \\
\text { - } \text { short extraction times } \\
\text { - } \quad \text { reduced use or no use of } \\
\text { - } \quad \text { stganic solvents } \\
\text { - stability against oxidation }\end{array}$ & $\begin{array}{l}\text { - surfactants could be risky } \\
\text { for health } \\
\text { - } \text { phase inversion } \\
\text { microemulsions could } \\
\text { require development of } \\
\text { complex systems that may be } \\
\text { time-consuming }\end{array}$ \\
\hline $\begin{array}{l}\text { Water-induced } \\
\text { hydrocolloidal } \\
\text { complexation }\end{array}$ & $\begin{array}{l}\text { formation of lycopene and } \\
\text { pectin colloidal complexes } \\
\text { in an aqueous } \\
\text { environment that can be } \\
\text { recovered by } \\
\text { sedimentation or } \\
\text { centrifugation }\end{array}$ & $\begin{array}{l}\text { - small amount of } \\
\text { organic solvents } \\
\text { - high selectivity } \\
\text { - high purity }\end{array}$ & $\begin{array}{l}\text { - need of a subsequent } \\
\text { recovery step } \\
\text { - extraction yield comparable } \\
\text { to that of classical organic } \\
\text { solvent extraction }\end{array}$ \\
\hline
\end{tabular}

${ }^{1}$ see Reference [35].

\section{Extraction of Lycopene from TBPs}

Classical Organic Solvent Extraction Technique (COSE)

The amount of lycopene recovered from tomato waste strictly depends on starting material and extraction methods. Because of its non-polar nature, lycopene can be extracted from suitable organic solvents [36,37]. In addition to the choice of the appropriate solvent, it is necessary to optimize several parameters including ratio solvent/matrix, temperature and extraction time in order to increase the recovery of the target compounds. The most common solvent techniques for the extraction of lycopene for TBPs are extraction by Soxhlet apparatus or mechanical stirring. The former allows a higher extraction yield; however, long time and high temperature applied during Soxhlet extraction can degrade heat-sensitive compounds [38]. Mixture design procedure can be used to formulate solvent mixtures to recover lycopene. A ternary system (n-hexane-ethanol-acetone) was investigated resulting in a lycopene extraction yield higher than $95 \%$ and providing a tomato oleoresin with high lycopene content [39]. The main drawback of the conventional solvent-based extraction procedures is the toxicity of traces of solvents that can remain causing long-term effects including leukemia [40], renal injury [41] and neurotoxicity [42]. Moreover, an increase in production cost is expected in the evaporation of the solvent and in the purification step. Despite the efforts in optimizing the solvent extraction process over the last decade, this method has a high environmental impact, and therefore new and more eco-sustainable techniques are investigated. 


\section{Pretreatments of TBPs Before Extraction}

\subsection{Pulsed Electric Fields (PEF) Treatment}

Pulsed electric fields (PEF) treatment is a method that uses a potential difference between two electrodes among which biological materials are placed. The application of electric field $(0.5-80 \mathrm{kV} / \mathrm{cm})$ pulses on plant matrices induces electropermeabilization allowing a higher extraction yield of plant metabolites [43]. At first, the cell disintegration index must be used to find the conditions where the degree of cell membrane permeabilization is the highest. After that, a PEF pre-treatment with moderate electric field intensity and low energy input increases the permeabilization of membranes of plant cells, enabling high recovery yields of intracellular compounds before solvent extraction [44]. PEF has been used successfully for the extraction of tomato pulp which leads to samples with a higher concentration of lycopene than the untreated samples [45] and subsequently applied to the recovery of lycopene from tomato waste. In a study by Pataro et al. [46], a PEF processing was performed on tomato peel before being subjected to extraction with acetone at different temperatures up to $50{ }^{\circ} \mathrm{C}$. Compared to untreated samples, the optimal energy input of $5 \mathrm{KJ} / \mathrm{Kg}$ at the field strength of $5 \mathrm{kV} / \mathrm{cm}$ enhanced the total carotenoids content and the ferric-reducing antioxidant power of the extract. As confirmed by high-performance liquid chromatography (HPLC) analysis, no isomerization or degradation of carotenoids occurred [46]. This method has been applied efficiently before peel extraction with either acetone or ethyl lactate [47] or on juicing residues before acetone extraction [48], obtaining higher lycopene yield with acetone which showed better capability to penetrate the plant cells of peel tissue and to solubilize a greater amount of intracellular lipophilic compounds.

\subsection{Enzyme-Assisted Extraction (EAE)}

This eco-sustainable technique involves the use of enzymes such as cellulase, pectinase and hemicellulase that catalyze the hydrolytic cleavage of structural components of the cell wall of the waste product; consequently, an increase in permeability allows one to reach high extraction yields. In addition, EAE of compounds from natural matrices leads to a reduction in extraction time and in using an organic solvent. Nevertheless, EAE has some limitations that include enzyme cost for processing high amounts of matrices; moreover, the enzymes currently available cannot completely hydrolyze cell walls [49]. In this context, the effects of cellulase and pectinase before the extraction of lycopene by petroleum ether and acetone $(1: 1 \mathrm{v} / \mathrm{v})$ were investigated [50] showing the pectinase more effective than cellulase in obtaining lycopene from tomato peels. A similar result was reported by Ranveer et al. 2013 [51] who found higher lycopene recovery for tomato peel treated with $2 \%$ pectinase and extracted with hexane:acetone:ethanol 50:25:25 $v / v$. This enzymatic pretreatment was then optimized ( $\%$ pectinase, $\mathrm{pH} 5.5,4 \mathrm{~h}$ incubation, $\left.45^{\circ} \mathrm{C}\right)$ [52]. Furthermore, the recovery of carotenoids by using a mixture of hydrolytic enzymes was found to be a good approach [53]. The recovery of lycopene from tomato waste (peel and seeds) was extensively investigated [54] by using a pectinolytic enzyme (Pectinex Ultra SP-L), a cellulolytic enzyme (Celluclast) and a combination of carbohydrases (including arabanase, cellulase, $\beta$-glucanase, hemicellulase and xylanase, named Viscozyme L) alone and in combination. A mixture of Celluclast and Pectinex $\left(\mathrm{T}=40{ }^{\circ} \mathrm{C}\right.$, enzymatic reaction time $=5 \mathrm{~h}$, enzyme:substrate ratio $=0.2 \mathrm{~mL} / \mathrm{g}$, enzyme:enzyme ratio $=1$ ) followed by ethyl acetate extraction (solvent:substrate ratio $=5 \mathrm{~mL} / \mathrm{g}$, extraction time $=1 \mathrm{~h}$ ) showed the highest lycopene recovery. The study conducted by Lavecchia and Zuorro [55] investigated the pretreatment of tomato peel with four food-grade enzyme preparations (Citrozym CEO and Ultra L, Peclyve EP and LI) with pectinolytic, cellulolytic and hemicellulolytic activities followed by extraction with hexane, finding that the enzyme preparation Peclyve LI enhances more lycopene extraction from peels. After that, the effect of solvent extraction on yields was investigated using hexane, ethyl acetate or a ternary mixture (hexane:acetone:ethanol 50:25:25 v/v/v) at different incubation times (0.5-15 h). After the pretreatment with the enzymes, the extraction yield of lycopene was 3- to 25-fold higher than the untreated matrix, with the highest yield obtained with the ternary mixture after $1 \mathrm{~h}$ of enzymatic treatment 
since longer reaction time leads probably to oxidation of lycopene. More recently, the same authors [56] investigated the optimization of the process by response surface methodology (RSM), based on statistical and mathematical techniques. The factors investigated included extraction temperature, extraction time and enzyme load with a mixture of Peclyve PR and Cellulyve $50 \mathrm{LC}$ in equal volumes to catalyze the enzymatic reaction, finding the following optimal extraction conditions: $\mathrm{T}=30^{\circ} \mathrm{C}$, extraction time $=3.18 \mathrm{~h}$ and enzyme load $=0.16 \mathrm{~kg} / \mathrm{kg}$. A similar approach was followed by Lombardelli et al. [57] in order to recover carotenoids from unsold tomatoes: a mixture of polygalacturonase, pectin lyase, cellulase and xylanase was investigated, while the optimal conditions $\left(50^{\circ} \mathrm{C}, \mathrm{pH}=5.5\right)$ by using an enzymatic mixture with a total dosage of $25 \mathrm{U} / \mathrm{g}$ for $180 \mathrm{~min}$ were identified by the RSM analysis. Interestingly, the extraction was performed by an environmentally friendly condition, as proposed by Cuccolini et al. [58]. The method involves first treatment with $\mathrm{NaOH}$ solution which allows one to open the tomato peel cell wall, dissolving the layer that cements the cells, and the subsequent enzymatic hydrolysis by cellulase and pectinase allowing to isolate the carotenoid-accumulating plastids named chromoplasts. Lycopene is stored inside the chromoplasts incorporated into lipoproteins that confer its stability. At this point, a protease eliminates proteins bound to the chromoplasts, providing a final product lycopene-rich with a 30-fold increase in lycopene contents compared to untreated peels.

\section{Supercritical Fluid Extraction (SFE) of TBPs}

A promising eco-friendly method is supercritical fluid extraction (SFE) that uses supercritical $\mathrm{CO}_{2}\left(\mathrm{scCO}_{2}\right)$ "green technology" for its advantages. Indeed, it is harmless, environmentally safe and highly selective because of low viscosity, high diffusivity and liquid-like density [59]. Furthermore, it is quickly accessible and simply removed from products, and, also, critical $\mathrm{CO}_{2}$ temperature is close to room one, and therefore it is also suitable for thermolabile substances [60]. Due to its non-polar nature, $\mathrm{CO}_{2}$ has been used successfully for the extraction of non-polar compounds from plants $[61,62]$. SFE demonstrated to be a proper method for the extraction of lycopene without organic solvent residues, thus overcoming the main issues in extracting lycopene: its solubility and stability. Indeed, lycopene is water-insoluble but soluble in highly toxic organic solvents and decomposes easily over time. There are numerous reports describing the successful extraction of lycopene from tomato materials by SFE plus several studies reporting the effects of different independent variables, such as pressure, temperature, flow rates and co-solvent or modifier concentrations. The choice of the SFE operating conditions is necessary for reaching the best possible extraction efficiency, that is, the maximum amount of material that can be extracted at a certain temperature, pressure and flow rate. Indeed, the optimization of such parameters is needed to achieve a high recovery of lycopene. Kehili et al. extracted lycopene and $\beta$-carotene from TBP peels with $\mathrm{scCO}_{2}$ at $50-80{ }^{\circ} \mathrm{C}, 300-500$ bar and flow rates of 3-6 $\mathrm{g} \mathrm{CO}_{2} / \mathrm{min}$ for $105 \mathrm{~min}$ on ground tomato peels of $300 \mu \mathrm{m}$ particle size [63]. The relative extraction yields ranged from $32.02 \%$ to $60.85 \%$ for lycopene and from $28.38 \%$ to $58.8 \%$ for $\beta$-carotene, considering as maximum extractable amounts $1198 \pm 72 \mathrm{mg} / \mathrm{kg}$ and $27.94 \pm 0.06 \mathrm{mg} / \mathrm{kg}$, on a dry basis, of lycopene and $\beta$-carotene, respectively, obtained with Soxhlet extraction with $n$-hexane for $12 \mathrm{~h}$. In particular, the maximum lycopene $(60.85 \%$, $728.98 \pm 31 \mathrm{mg} / \mathrm{kg})$ and $\beta$-carotene $(58.8 \%, 16.43 \pm 0.84 \mathrm{mg} / \mathrm{kg})$ recoveries were obtained under $400 \mathrm{bar}, 80^{\circ} \mathrm{C}$ and $4 \mathrm{~g} \mathrm{CO}_{2} / \mathrm{min}$. Furthermore, a comparison between SFE and conventional maceration extraction was made, starting from the same TBP peels as for SFE. This method produced $608.94 \pm 10.05 \mathrm{mg} / \mathrm{kg}, 320.35 \pm 3.4 \mathrm{mg} / \mathrm{kg}$ and $284.53 \pm 7.0 \mathrm{mg} / \mathrm{kg}$ using $n$-hexane, ethyl acetate and ethanol, respectively. The $n$-hexane was the most convenient solvent, $50.83 \%$, while ethyl acetate and ethanol led to lower yields, $26.74 \%$ and $23.75 \%$, respectively. Therefore, the authors concluded that $\mathrm{scCO}_{2}$ provided higher lycopene recovery with respect to solvent extraction, despite the limited solubility of lycopene in supercritical fluids. Rozzi et al. [64] determined the temperature, pressure, flow rate and $\mathrm{CO}_{2}$ volume effects on SFE of lycopene from a by-product of tomato processing. The 
parameters were evaluated on the recovery in tomato seeds and skins (51.6\% dry matter). It was proven that both temperature and pressure influenced the extraction of lycopene and that an optimum temperature and pressure combination resulted in extracting $61.0 \%$ of the lycopene present in the sample. The authors hypothesized that this optimum could be ascribed to a decrease in diffusivity of $\mathrm{CO}_{2}$ as its density increases which could hinder the $\mathrm{CO}_{2}$ capability of diffusing throughout the sample, thus dissolving more solute. Another hypothesis was that the pressure increase could lead to a compaction of the sample, similarly hindering the ability of $\mathrm{CO}_{2}$ to diffuse. SFEs were carried out with $\mathrm{scCO}_{2}$ at seven temperatures $\left(32-86^{\circ} \mathrm{C}\right)$ and six pressures $(13.78-48.26 \mathrm{MPa})$. The effect of $\mathrm{scCO}_{2}$ flow rate and volume was also evaluated. Results indicate that the amount of extracted lycopene increased with high temperature and pressure until a limit at $86{ }^{\circ} \mathrm{C}$ and $34.47 \mathrm{MPa}$, after which it decreased. Furthermore, the optimum conditions to extract lycopene from $3 \mathrm{~g}$ of raw material were defined using a flow rate of $2.5 \mathrm{~mL} / \mathrm{min}$ and $500 \mathrm{~mL}$ of $\mathrm{CO}_{2}$ (indeed, a higher amount of $\mathrm{CO}_{2}$ led to a lycopene amount plateau). These conditions granted $61.0 \%$ of lycopene extraction $(7.19 \mu \mathrm{g}$ lycopene $/ \mathrm{g})$. Notably, the initial lycopene content of the tomato seeds and skins was $11.8 \mu \mathrm{g}$ of lycopene per gram of raw material (wet weight) or $24.5 \mu \mathrm{g}$ of lycopene per gram of dry material (dry weight) as determined by chloroform extraction. The influence of temperature as a parameter for reaching an optimum in SFE of lycopene was also confirmed by Pellicano and coworkers [60]. Even so, at the temperature of $80{ }^{\circ} \mathrm{C}$, the authors observed a decrease in the lycopene solubility in $\mathrm{scCO}_{2}$, probably due to its thermal degradation. For this reason, they decided to operate at $60^{\circ} \mathrm{C}$. Indeed, they observed a slight increase in recovering lycopene when the temperature rose from 40 to $60{ }^{\circ} \mathrm{C}$ and achieved a plateau before reaching $80^{\circ} \mathrm{C}$. Pressure effects on lycopene extraction were similar to temperature ones. Indeed, the lycopene recovery increased with the pressure, reaching a plateau (corresponding to the maximum yield of extraction of $4.37 \%$, that is, $0.79 \mathrm{~g}$, from about $18 \mathrm{~g}$ of dehydrated tomato seeds and skins) at 550 bar after $80 \mathrm{~min}$. The authors claimed that lycopene recovery is mainly dependent on the interaction between pressure and temperature. Indeed, the pressure increase leads to higher $\mathrm{CO}_{2}$ density which in turn determines an increase in the solvating power of the supercritical fluid (with a consequent greater lycopene extraction). This effect was also observed by Topal et al. who noticed that higher pressure is responsible for quantitative recoveries and stronger interactions between the fluid and the matrix [65]. On the other hand, a higher temperature means a density decrease (and therefore a decrease in the solvent power) while keeping constant the pressure parameter. Even so, one must account for two factors: (a) the density decrease becomes smaller at high pressures, and (b) the rise in temperature means also an increase in solubility (due to the sublimation temperature increase in the solute) that opposes the density decrease. Therefore, lycopene solubility in $\mathrm{CO}_{2}$ increases when temperature and pressure parameters are both increased. By exceeding in elevating the temperature, degradation through isomerization and auto-oxidation of lycopene was often encountered, as observed by Mayeaux et al., especially during long heating times [66]. The effects of temperature and pressure on SFE were also investigated by Vàgi and colleagues who analyzed also the influence of air-dried and deep-frozen storages on lycopene recovery [67]. The authors obtained the highest concentration of carotenoids with $90.1 \%$ of lycopene at 460 bar and $80{ }^{\circ} \mathrm{C}$ (no degradation of the biologically active compounds happened), observing that the extraction yields were higher of the sample stored at deep-frozen state for 1 year than that stored at room temperature for the same time. In particular, the amount of carotenoids in the deep-frozen stored sample was 10 times higher than that present in the air-dried stored sample, with lycopene conversed in a higher amount too. Interestingly, Zhang and colleagues studied the effect of the operating parameters on lycopene $\mathrm{scCO}_{2}$ extraction from freeze-dried tomato peels and seeds [68]. In particular, the authors investigated the variation of extraction yield and lycopene content at different temperatures $\left(40^{\circ} \mathrm{C}, 50^{\circ} \mathrm{C}\right.$ and $\left.60{ }^{\circ} \mathrm{C}\right)$, pressures $(35 \mathrm{MPa}, 40 \mathrm{MPa}$ and $45 \mathrm{MPa})$ and particle size (three-degree index). The highest lycopene concentration was obtained at $40 \mathrm{MPa}, 60^{\circ} \mathrm{C}$ (32.52 $\mathrm{g} / 100 \mathrm{~g}$ dry material) and with the mean particle sizes of tomatoes 
peels and seeds powder of $0.30 \mathrm{~mm}$, while the extract rich in $\beta$-carotene was obtained at below $30 \mathrm{MPa}$. Another important parameter is the flow rate of $\mathrm{scCO}_{2}$. It influences the extraction efficiency by controlling the amount of solvent (that is, $\mathrm{CO}_{2}$ ) to be used and the extraction time. The higher the flow rate used, the faster extractions and the higher recoveries are obtained since it can overcome the interface resistance for lycopene transport from tomato skin to $\mathrm{CO}_{2}$. However, exceeding flow rates produces undesirable results due to decreased contact times between solvent and solute [65]. The extraction time is another important factor influencing the yield of the process. For the extraction of lycopene, Baysal and coworkers [69] observed that the highest yield was obtained at an extraction time of $2 \mathrm{~h}$, compared to 1 or $3 \mathrm{~h}$. In the former case, the extraction time was not sufficient to dissolve the solute in the solvent, while over $3 \mathrm{~h}$ the occurrence of degradation increased. Remarkably, Huang et al. reported the effects of temperature, pressure and extraction time on lycopene yield from tomato pomace utilizing ethanol-modified $\mathrm{scCO}_{2}$ [70]. They observed that not just pressure and temperature influenced lycopene yields, but it was more precisely the interaction between pressure, temperature and extraction time. A polynomial regression model was suggested that allowed identifying the optimum conditions at $57{ }^{\circ} \mathrm{C}$, $40 \mathrm{MPa}$ and $1.8 \mathrm{~h}$. These conditions led to a lycopene yield of $28.64 \mathrm{mg}$ from $100 \mathrm{~g}$ dried tomato pomace (recovery $=93 \%$ ). An important role in $\mathrm{scCO}_{2}$ extraction of lycopene is also played by co-solvents or modifiers, employed to enhance extraction efficiency and cost-effectiveness. Modifiers are like co-solvents in that they aid in the extraction, but modifiers are added directly to the sample before extraction, instead of with the solvent (like co-solvents) [64]. Numerous chemical modifiers (such as water, ethanol and methylene chloride) were tested to enhance the extraction process. Co-solvents or modifiers added in small amounts ( 1 to $5 \% \mathrm{~mol}$ ) can modify the overall extraction fluid characteristics in terms of polarity, solvent strength and specific interactions. As a result of these modifications, a significant alteration of density and compressibility of the supercritical fluid happens. The addition of small amounts of water, vegetable oil or ethanol can significantly enhance the extraction of non-polar compounds such as lycopene. Shi et al. reported the use of ethanol as a modifier [71], observing that the ethanol, diluting the extract, reduced the viscosity and thus enhanced the extraction flow. The increase in recovery showed a linear correlation with that of the ethanol concentration at $45^{\circ} \mathrm{C}$ when it was increased from 5 to $10 \%$ (lycopene recovery increase of $11 \%$ ). A further increase from 10 to $15 \%$ led to a lower increase in lycopene recovery $(6 \%)$. These results highlight the importance of selecting the proper concentration of the modifier to improve extraction efficiency. Another advantage of adding co-solvents or modifiers is the ability to swell the matrix, favoring the penetration of the $\mathrm{CO}_{2}$. The lycopene recovery increased by increasing the water concentration in tomato skin materials, even if an excess of the water content (higher than $18 \%$ ) causes mechanical difficulties due to a material transport impairment [72]. In this regard, the moisture content must be considered for SFE. Given the lipophilic properties of lycopene, edible oils as alternative modifiers were considered to improve SFE. It was also observed that the presence of co-solvents has a beneficial role in pigment stability [73]. Moreover, one might keep in mind that such modifiers have the advantage of being edible, and thus they do not need to be subsequently separated from the product. Several vegetable oils were studied (almond oil, peanuts, hazelnuts and sunflower seeds) by Margotta et al., but only in the case of hazelnut oil (cheaper and with a low acidity preventing the lycopene degradation during extraction) higher extraction yields were achieved [73]. As mentioned above, given that a higher quantity of oil provides a more diluted extract, the authors decided to choose an average value of $10 \%$. They observed that this oil allowed avoiding the degradation of lycopene, keeping the pigment stable over time. However, the use of organic solvents has two drawbacks: (a) it is not specific for lycopene, thus extracting many other pigments (carotenes, xanthophylls) and so causing a long and expensive purification process of lycopene; and (b) the raw material used becomes a special waste that will have to be incinerated with a considerable cost increase. Differently, Perretti et al. studied the SFE of lycopene from dried tomato pomace using sunflower oil and ethanol [74]. After 
the supercritical fluid fractionation, the authors collected four fractions (at 30, 60, 120 and after $120 \mathrm{~min}$ ) and analyzed the lycopene concentration under different pressures (10 and $30 \mathrm{MPa}$ ) and flow rates ( 5 and $15 \mathrm{~kg} / \mathrm{h}$ ). The best recoveries were obtained in the $30 \mathrm{~min}$ fraction operating at $10 \mathrm{MPa}$ and flow rate of $5 \mathrm{~kg} / \mathrm{h}$ and in the $120 \mathrm{~min}$ fraction operating at $30 \mathrm{MPa}$ and $15 \mathrm{~kg} / \mathrm{h}$. Moreover, by comparing the lycopene concentrations of the fractions obtained at 30 and at $60 \mathrm{~min}$ in the same operating conditions, the higher content of lycopene of the $30 \mathrm{~min}$ fraction confirmed the positive role of ethanol as a co-carrier, providing the higher solubility of lycopene in the presence of this solvent in the column. Interestingly, Machmudah et al. described the use of tomato seed oil as an alternative to organic solvents to increase the solvating power of $\mathrm{scCO}_{2}$ in order to reduce the drawbacks of organic solvents [75]. Thus, they studied the effects of temperature, pressure and flow rate on lycopene and $\beta$-carotene recovery using tomato seed oil as a co-solvent as well as the composition of oil from the tomato seed. The lycopene and $\beta$-carotene recovery was considerably enhanced with tomato seed oil as a co-solvent and, after 120 min of extraction, was basically constant. In addition, an increase in the recovery of lycopene, $\beta$-carotene and tomato seed oil was observed by increasing pressure but not the temperature. Indeed, the $\beta$-carotene recovery slightly decreased with higher temperature, probably due to both a higher degradation of $\beta$-carotene and to a predominating effect of the density decrease than the solute vapor pressure increase (by increasing the temperature). Conversely, the lycopene recovery slightly increased by increasing temperature due to an increased vapor pressure of the lycopene that causes an increased lycopene solubility. Concerning the tomato seed oil extraction, a temperature increase did not significantly affect the recovery. Furthermore, the $\mathrm{CO}_{2}$ flow rate did not appreciably influence the lycopene, $\beta$-carotene or seed oil recovery. The authors argued that the solubility of the solute in $\mathrm{scCO}_{2}$ limited the extraction. The tomato peel/seed ratio was also important on lycopene and $\beta$-carotene recovery because an increase in recovery was observed by increasing the seed amount. Still, this was true up to a maximum peel/seed ratio because further increase led to a decrease in the recovery. The authors hypothesized that this increase could cause a higher extraction of seed oil that may hinder $\mathrm{CO}_{2}$ transport into the solid matrix. A fundamental aspect that needs to be considered is the degree of degradation via isomerization and oxidation of lycopene and $\beta$-carotene. Therefore, several attempts have been described in the literature to study the possibility of obtaining the most stable isomer (all-trans form) with SFE, avoiding the oxidative degradation and the formation of artefactual isomers during the process. Gòmez-Prieto et al. reported a method of SFE that allowed minimizing the trans-to-cis isomerization of lycopene [28] without using co-solvents. Given this as the main purpose of their work, the authors maintained an extraction temperature as low as possible, optimizing the lycopene solubility by setting an adequate pressure parameter (and the density of $\mathrm{CO}_{2}$ consequently). In particular, they noticed that keeping the temperature at $40{ }^{\circ} \mathrm{C}$ and varying the pressure between 77 and 281 bar, a negative or non-significant effect of the temperature is obtained, probably due to a balance between the supercritical fluid density and the solute vapor pressure. Moreover, the extraction times were set as low as possible (30 $\mathrm{min})$ in order to further reduce the possibility of isomerization. The authors observed that the amount of trans-lycopene rose (and the cis form decreased) as the pressure increased due to the corresponding increase in $\mathrm{CO}_{2}$ density. In particular, they obtained an extract with $88 \%$ all-trans lycopene and $12 \%$ cis-lycopene working at 281 bar (providing a density of $0.90 \mathrm{~g} / \mathrm{mL}$ ), ascribing the presence of a cis-isomer to the solubility differences of trans and cis forms in $\mathrm{CO}_{2}$ rather than their trend to undergo isomerization. Further studies reported that no dramatic effect on the isomerization degree happens at temperatures below $75{ }^{\circ} \mathrm{C}$ as reported by Mayer-Miebach et al. [76] or below $70{ }^{\circ} \mathrm{C}$ (as described by $\mathrm{Yi}$ et al.) [72]. Indeed, the ratio all-trans:cis-lycopene showed the major influence on the lycopene isomer composition at temperatures above $70^{\circ} \mathrm{C}$, with variations from 1.70 to 1.62 at extraction temperatures between $40{ }^{\circ} \mathrm{C}$ and $70{ }^{\circ} \mathrm{C}$ and from 1.62 to 1.32 at temperatures between $70{ }^{\circ} \mathrm{C}$ and $100{ }^{\circ} \mathrm{C}$. These modifications in the all-trans:cis-lycopene ratio indicated the generation of the cis-isomers. Interestingly, Shi et al. described an increase in the 
proportions of cis-isomers using olive oil as a modifier rather than ethanol or water. The authors explained this behavior by that cis-isomers are less prone to crystallization and more soluble in lipophilic solvents such as oil.

\section{Ultrasonic-Assisted Extraction}

The use of ultrasounds has been successful in various food industry processes such as emulsion, crystallization, filtration, separation, defoaming, extrusion, fermentation and microbial inhibition [77-79]. The sound waves produced by an ultrasound probe at frequencies higher than human hearing cause a mechanical impact, allowing greater penetration of the solvent into the plant body, known as the "sponge effect". In addition, high-energy cavitation bubbles containing solvent vapor are created. These bubbles, imploding near the cell walls, cause very high local temperatures and an increase in pressure that cause the destruction of the cell walls. The combination of these effects intensifies the penetration of the solvent and satisfies a sufficient mixing to extract high quantities of active components. In addition to facilitating extraction, ultrasound, however, can also produce highly reactive free radicals in solutions [80-82].

In the case of lycopene, some recent studies show that ultrasonic extraction accelerates the extraction rate and increases the yield by about 10\% [83-85].

In a 2014 study by Yilmaz et al. [86], the difference in extraction of lycopene and $\beta$ carotene from industrial tomato waste was evaluated between the classical organic solvent extraction technique (COSE) and the ultrasound technique. With normal organic solvents, yields increase over time. In detail, there is growth for extraction periods of $10 \mathrm{~min}$ and $20 \mathrm{~min}$ while for longer periods of 30 and $40 \mathrm{~min}$, for example, the yields are similar for both lycopene and $\beta$-carotene. This can be explained by the decrease in the driving force of the osmotic equilibrium since the diffusion of carotenoids from the material to the solution in COSE occurs slowly so that the osmotic pressure between the inside and outside of the cell easily reaches equilibrium $[87,88]$. Using ultrasound, on the other hand, it was observed that the extraction yield increased exponentially already at $2 \mathrm{~min}$, then increased more gradually at $10 \mathrm{~min}$, to finally become constant during the extraction. The initial large increase in the extraction rate may be due to the large concentration gradient of $\beta$ carotene and lycopene between the pure extractor solvent and the material to be extracted. Subsequently, the concentration gradient decreases as the extraction proceeds and the extraction becomes more and more difficult thanks to the internal position of the cells. Similar results were observed for the extraction of all-trans lycopene from red grapefruit and lycopene from tomato processing waste $[88,89]$. In previous studies, comparable results were reported for the ultrasonic extraction of all-trans lycopene and time was found to be the most important factor affecting the extraction yield. Most trans-lycopene could be extracted as early as the first third of the total extraction period. At this point, phenomena of degradation and the isomerization of lycopene would take place, leading, in fact, to a reduction in the quantity of substance. This could be attributed to the side effect of sonication called ultrasonic degradation [88-92]. With a significant increase in power from $50 \mathrm{~W}$ to $65 \mathrm{~W}$, then, the value of lycopene increases significantly, while the increase in the value of $\beta$-carotene between $50 \mathrm{~W}$ and $65 \mathrm{~W}$ is not significant. Instead, the application of 90 $\mathrm{W}$ has a significant effect on both lycopene and $\beta$-carotene. Cavitation and thermal effects play an equally important role. With an increase in potency, more energy is transferred for cavitation, and this certainly leads to an increase in the yield of lycopene and $\beta$-carotene. At low ultrasonic intensities, the thermal effect can be ignored because the heat produced by the ultrasound is completely diffused. With the further increase in ultrasonic intensity, however, the cavitation effect becomes less important than the thermal effects during the extraction of sensitive products such as carotenoids [79,87]. Chen et al. [29] claimed that, during sonication, the extreme physical conditions of temperature and pressure caused the carotenoid isomerization. In addition to improving extraction efficiency, high ultrasonic power could cause thermal degradation to thermally sensitive components such as $\beta$ carotene $[93,94]$. As a result, the lycopene content increases over time from $15 \mathrm{~min}$ to 
$30 \mathrm{~min}$ in all ultrasonic power ranges. The $\beta$-carotene, on the other hand, begins to decline at $90 \mathrm{~W}$. This can be explained by the differences in sensitivity of lycopene and $\beta$-carotene in thermal effects. In order to optimize lycopene extraction parameters by combining various techniques including sonication [95], Amiri-Rigi and coworkers studied the effect of the different ultrasonic intensities $(30,50,70$ and $90 \mathrm{~W})$ and of the sonication durations $(3,5$ and $8 \mathrm{~min}$ ) on the lycopene content in the microemulsion phase. In a constant exposure time, the lycopene content in the microemulsion phase increased significantly as the ultrasonic power increased from 30 to $50 \mathrm{~W}$. However, as the ultrasonic power increased beyond $50 \mathrm{~W}$, the amount of lycopene extracted saw a slight decline. The increase in the ultrasound exposure time in constant power, on the other hand, resulted in a progressive reduction of the concentration of lycopene with the exception of the $30 \mathrm{~W}$ in which the extractability was improved by increasing the exposure time. Ultimately, the highest lycopene recovery was achieved using an ultrasonic power of $50 \mathrm{~W}$ and an exposure time of $3 \mathrm{~min}$. Subsequently, the sonication power of $50 \mathrm{~W}$ was chosen for further investigation to see if a reduction in the exposure time to sonication was possible while improving the total recovery of the substance. From the reported data, the amount of lycopene extracted slightly decreased with an increasing sonication duration from 30 to $180 \mathrm{~s}$, while no significant differences were shown at 30,60, 90 and $120 \mathrm{~s}$. Overall, the power of $50 \mathrm{~W}$ and the exposure time of $30 \mathrm{~s}$ were adopted as optimal operating parameters for the sonication pretreatment of tomato industrial waste powder. Studies also show that ultrasonic degradation of cellular tissue is extremely rapid and occurs within the first $30 \mathrm{~s}$ of sonication treatment [96]. Probably, the reduction in the concentration of lycopene at an increasing intensity of sonication may be due to the activity of enzymes, such as lipoxygenase, because of greater fragmentation of the cell wall induced by sonication. Lipoxygenase is able to oxidize lycopene and result in the isomerization of the double bonds of lycopene from trans to cis. In a previous study by the same authors on wet tomato pomace (mixture of skins and seeds), with a more intense sonication, a different treatment (power $20-37 \mathrm{~W}$, temperature $10{ }^{\circ} \mathrm{C}, 15 \mathrm{~min}$ ) was necessary to improve the efficiency [95].

\section{Microwave-Assisted Extraction}

Among the eco-friendly techniques, microwave-assisted extraction (MAE) has been accepted as a potential and powerful alternative for the extraction of bioactive compounds from plant material [97,98] and food industrial residues [99]. MAE combines microwave and traditional solvent extraction. In fact, during MAE, the solvent penetrates into the solid matrix and soluble products are extracted into a fluid until reaching a concentration limited by the characteristics of the solid. Microwaves are electromagnetic waves with frequencies ranging from $300 \mathrm{MHz}$ to $300 \mathrm{GHz}$ with two oscillating fields that are perpendicular such as electric field and magnetic field. These electromagnetic waves change the cell structure, a principal difference with respect to conventional extraction methods (solid-liquid or simply extraction). Whereas in conventional extraction the heat is transferred from the heating medium to the interior of the sample, in MAE, the heat is dissipated volumetrically inside the irradiated medium (volumetric heating) [100]. MAE becomes a suitable option in the place of traditional techniques thanks to its advantages: shorter extraction time, higher extraction rate and lower use of solvents and costs [101]. The first use of MAE goes back to 1986 by Ganzler et al. [102]. The authors reported the possibility to use MAE for extracting diverse types of compounds from soil, seeds, food and feed. Subsequently, several studies have reported the excellent performance in terms of recovery of the bioactive and nutritional components compared to other traditional extraction techniques. The basic principle of this extraction technique is that the moisture inside the cell evaporates due to the heat generated by the microwaves, and this process generates a high pressure on the cell wall causing modification of the physical properties of the biological tissues. This results in an increase in the porosity of the biological matrix which allows better penetration of the extraction solvent [103]. There are several factors that influence this technique: power, frequency and time of application, moisture content and size of the sample matrix 
plates, type and concentration of the solvent, ratio between solid and liquid, extraction temperature, extraction pressure and number of extraction cycles [104]. Among these factors, the choice of solvent is considered the most important critical point. Generally, the choice is made considering three physical parameters: (i) solubility, (ii) dielectric constant and (iii) dissipation factors. Solvents with a high dielectric constant, such as "water" and polar solvents, can absorb high microwave energy and are usually better solvents than non-polar ones [90,103]. In order to maximize the recovery of lycopene from tomato by-products, different auxiliary extraction technologies have been tested. Ho et al. investigated a possible alternative to conventional extraction methods using, as a matrix to be extracted, tomato peels derived from a local processing plant as a byproduct in the production of tomato concentrate [105]. The skins were first neutralized with hydrochloric acid until a $\mathrm{pH}$ of 7 was obtained and then dried. In order to better facilitate extraction, the skins were ground until a particle size $<0.5 \mathrm{~cm}$ was achieved and then used. The response surface methodology (RSM) was used for obtaining the optimum conditions (solvent, time and microwave power) to recover lycopene and evaluate the effect of treatment on all-trans yields. The optimal conditions were: 0:10 solvent ratio at $400 \mathrm{~W}$ that provided $13.59 \mathrm{mg} / 100 \mathrm{~g}$ (all-trans lycopene). RSM indicated that ethyl acetate was a preferable MAE solvent to recover lycopene with respect to hexane (that extracted less lycopene). HPLC-DAD showed a clear improvement of all-trans and total lycopene yields by using MAE, with respect to conventional methods that led to higher amounts of cis-isomers [105]. This technique was also combined with ultrasound, creating ultrasound microwave-assisted extraction (UMAE). Lianfu et al. compared these two methods applied to lycopene extraction from tomatoes, with the aim of highlighting their advantages and disadvantages. The authors analyzed the effect of power (in UMAE), temperature (in UAE) and time and solid/solvent ratio (in both extraction techniques). In this work, RSM was used for obtaining the best conditions (solvent, time and microwave power) for lycopene extraction. The analyzed material was the tomato puree obtained after a centrifugation process. The optimum of UMAE was reached at: microwave power, $98 \mathrm{~W}$; extracting time, $367 \mathrm{~s}$; solvent/tomato paste ratio, 10.6:1. Differently, the optimum for UAE was: extracting temperature, $86.4^{\circ} \mathrm{C}$; extracting time, $29.1 \mathrm{~min}$; solvent/tomato paste ratio, 8.0:1. By comparing these two methods, it is evident that UMAE overcomes the gaps of UAE, being, therefore, a more attractive method [94].

\section{Microemulsion Technique}

The microemulsion technique (MET) represents another promising extraction method thanks to the exceptional physicochemical properties such as perfect stability, low viscosity, great solubilization capacity for both hydrophilic and lipophilic compounds and the increase in bioavailability of nutraceuticals. This technique, using a wide variety of surfactants, has already been successfully applied in the extraction of various nutraceuticals and organic compounds such as phenols, enzymes and proteins from liquids [106], oils $[107,108]$ and proteins and glucosinolates from oilseed cruciferous meals [109]. This lycopene extraction was developed using a lecithin-based olive oil microemulsion [110] consisting in a water-based formulation with a small droplet size. In this study, soybean lecithin was used as an emulsifier, 1-propanol was used as a co-surfactant since it is considered safe in food preparation as a flavoring and coloring agent [111], while olive oil was used to enhance lecithin solubility. The optimum ratios of lecithin/1-propanol, olive oil and water (53.33:26.67:10:10 \%wt) resulted in a very high extraction yield (88\%) from tomato pomace after four extraction cycles. Other studies [96,112] investigated the use of different emulsifiers and co-surfactants in a multi-step extraction where a pretreatment with ultrasounds $(50 \mathrm{~W}, 30 \mathrm{~s})$ and pectinase $\left(60 \mathrm{~min}, \mathrm{pH}=4.5,45^{\circ} \mathrm{C}\right)$ was applied before the microemulsion extraction of tomato waste provided the highest extraction yield when saponin and glycerol were used as a surfactant and co-surfactant, respectively. 


\section{Water-Induced Hydrocolloidal Complexation}

This kind of extraction is based on the complexation of lycopene and pectin induced by the addition of water to tomato pomace followed by the separation of lycopene and pectins using solvent extraction. In the first step, a dispersion of colloidal particles from tomato pomace in a water solvent is formed presumably because pectins act as a natural emulsifier [113] dispersing the lycopene bodies released by tomato cells into the solvent. Two successive centrifugations at different rpm values allowed separating debris and colloidal complex; lastly, the recovery of lycopene and other carotenes from the complex can be performed by a small amount of organic solvent. By this extraction, optimized using response surface methodology, the maximum recovery obtained was of $9.43 \mathrm{mg}$ carotenoid fractions $/ 100 \mathrm{~g}$ tomato pomace, with a purity of carotenoid-rich fractions of $92 \%$ [114].

\section{Conclusions}

Food waste and by-product production, occurring during food processing, is becoming an ever-increasing environmental issue. With the aim of increasing the eco-sustainability of the food processing industry and reducing the impact on the environment, a promising strategy is to reuse and exploit by-products before they become waste. Many of these biomaterials are, in fact, a source of valuable compounds, having, therefore, powerful nutritional and functional use. Nonetheless, reusing components from by-products is still in its infancy, highlighting the need to invest in research and for new recovery technologies. Recently, numerous advances have been made in conventional and novel techniques successfully applied for recovery and reuse of waste from industrial tomato processing, in particular for extracting lycopene from TBPs. Indeed, COSE shows several drawbacks, mainly due to the toxicity of solvent traces that can remain in the extract and the high environmental impact, and, therefore, new and more eco-sustainable techniques have been investigated. On one hand, pretreatments of TBPs before COSE, including PEF and EAE, allowed reaching high extraction yields and shorter extraction times, but they still require organic solvents' use downstream. On the other hand, various innovative techniques have been recently applied for the extraction of lycopene from TBPs, such as SFE. This environmentally friendly method showed several advantages such as low operating temperatures (that allow avoiding thermal degradation), high yields and selectivity and fast extraction times, and it is also free of organic solvents' residues. Yet, SFE is characterized by high power consumption, very expensive and complex equipment and elevated operating pressures that could represent a risk for the operators. Another promising extracting technique is $\mathrm{UAE}$, an eco-friendly method that allows high efficiency, low energy consumption and equipment costs, high extraction yields, short extraction time and that is basically harmless. However, limitations are related to difficulty in scaling up, possible degradation of thermolabile compounds, highly reactive free radical generation, low selectivity and limited extraction volumes. Similarly, the MAE method is characterized by similar disadvantages compared to UAE, even if the equipment costs are higher and the possibility of thermal degradation occurs more rarely. Nonetheless, this eco-friendly method allows reducing the amount of organic solvents and reaching short extraction times and high extraction yields. Two very recently described extraction methods are the microemulsion technique and the water-induced hydrocolloidal complexation, both promising and characterized by several advantages. Indeed, the first one allows high extraction yields, stability against oxidation and reduced use of organic solvents, even if it has some drawbacks (the residual presence of surfactants that could be risky for health and the development of complex systems that may be time-consuming). The water-induced hydrocolloidal complexation is characterized by high selectivity and high purity of the extracted compounds, but it needs a subsequent recovery step, and the extraction yields are comparable to that of classical organic solvent extraction. Taken together, these data could hopefully improve the awareness in reducing food waste as much as possible and increase the reuse of components from processing industry by-products. 
Author Contributions: Conceptualization, V.N.M., D.D.V. and R.C.; writing-original draft preparation, V.N.M., D.D.V., D.I. and A.M.; writing-review and editing, V.N.M., D.D.V., D.I., V.T., A.D.L. and A.M.; visualization, A.M., R.C., R.D.S. and L.S.; supervision, R.C., R.D.S. and L.S. All authors have read and agreed to the published version of the manuscript.

Funding: This research received no external funding.

Institutional Review Board Statement: Not applicable.

Informed Consent Statement: Not applicable.

Data Availability Statement: The data presented in this study are available on request from the corresponding author.

Conflicts of Interest: The authors declare no conflict of interest.

Sample Availability: Samples of the compounds are not available from the authors.

\section{References}

1. Torres-León, C.; Ramírez-Guzman, N.; Londoño-Hernandez, L.; Martinez-Medina, G.A.; Díaz-Herrera, R.; Navarro-Macias, V.; Alvarez-Pérez, O.B.; Picazo, B.; Villarreal-Vázquez, M.; Ascacio-Valdes, J.; et al. Food waste and byproducts: An opportunity to minimize malnutrition and hunger in developing countries. Front. Sustain. Food Syst. 2018, 2, 52. [CrossRef]

2. Baiano, A. Recovery of biomolecules from food wastes-A review. Molecules 2014, 19, 14821-14842. [CrossRef]

3. Castellana, S.; Ranzino, L.; Beritognolo, I.; Cherubini, M.; Luneia, R.; Villani, F.; Mattioni, C. Genetic characterization and molecular fingerprint of traditional Umbrian tomato (Solanum lycopersicum L.) landraces through SSR markers and application for varietal identification. Genet. Resour. Crop. Evol. 2020, 1-14. [CrossRef]

4. Tomatoes Statistics. Available online: https:/ / ec.europa.eu/info/food-farming-fisheries/farming/facts-and-figures/markets / overviews/market-observatories/fruit-and-vegetables/tomatoes-statistics_en (accessed on 4 April 2021).

5. Szabo, K.; Cătoi, A.-F.; Vodnar, D.C. Bioactive compounds extracted from tomato processing by-products as a source of valuable nutrients. Plant. Foods Hum. Nutr. 2018, 73, 268-277. [CrossRef] [PubMed]

6. PA Silva, Y.; Borba, B.C.; Pereira, V.A.; Reis, M.G.; Caliari, M.; Brooks, M.S.-L.; Ferreira, T.A. Characterization of tomato processing by-product for use as a potential functional food ingredient: Nutritional composition, antioxidant activity and bioactive compounds. Int. J. Food Sci. Nutr. 2019, 70, 150-160. [CrossRef]

7. Fărcaş, A.C.; Socaci, S.A.; Michiu, D.; Biriş, S.; Tofană, M. Tomato waste as a source of biologically active compounds. Bull. Univ. Agric. Sci. Vet. Med. Cluj-Napoca Food Sci. Technol. 2019, 76, 85-88. [CrossRef]

8. Maoka, T. Carotenoids as natural functional pigments. J. Nat. Med. 2020, 74, 1-16. [CrossRef] [PubMed]

9. Beltran, J.C.M.; Stange, C. Apocarotenoids: A new carotenoid-derived pathway. In Carotenoids in Nature, 1st ed.; Stange, C., Ed.; Springer: Cham, Switzerland, 2016; Volume 79, pp. 239-272.

10. Imran, M.; Ghorat, F.; Ul-Haq, I.; Ur-Rehman, H.; Aslam, F.; Heydari, M.; Shariati, M.A.; Okuskhanova, E.; Yessimbekov, Z.; Thiruvengadam, M.; et al. Lycopene as a natural antioxidant used to prevent human health disorders. Antioxidants 2020, 9, 706. [CrossRef] [PubMed]

11. Cha, J.H.; Kim, W.K.; Ha, A.W.; Kim, M.H.; Chang, M.J. Anti-inflammatory effect of lycopene in SW480 human colorectal cancer cells. Nutr. Res. Pract. 2017, 11, 90-96. [CrossRef]

12. Yin, Y.; Zheng, Z.; Jiang, Z. Effects of lycopene on metabolism of glycolipid in type 2 diabetic rats. Biomed. Pharm. 2019, 109, 2070-2077. [CrossRef]

13. Das, K.K.; Razzaghi-Asl, N.; Tikare, S.N.; Di Santo, R.; Costi, R.; Messore, A.; Pescatori, L.; Crucitti, G.C.; Jargar, J.G.; Dhundasi, S.A.; et al. Hypoglycemic activity of curcumin synthetic analogues in alloxan-induced diabetic rats. J. Enzym. Inhib. Med. Chem. 2016, 31, 99-105. [CrossRef] [PubMed]

14. Mein, J.R.; Lian, F.; Wang, X.D. Biological activity of lycopene metabolites: Implications for cancer prevention. Nutr. Rev. 2008, 66, 667-683. [CrossRef] [PubMed]

15. Chen, M.L.; Lin, Y.H.; Yang, C.M.; Hu, M.L. Lycopene inhibits angiogenesis both in vitro and in vivo by inhibiting MMP-2/uPA system through VEGFR2-mediated PI3K-Akt and ERK/p38 signaling pathways. Mol. Nutr. Food Res. 2012, 56, 889-899. [CrossRef] [PubMed]

16. Friedman, M.; Tam, C.C.; Kim, J.H.; Escobar, S.; Gong, S.; Liu, M.; Mao, X.Y.; Do, C.; Kuang, I.; Boateng, K.; et al. Anti-parasitic activity of cherry tomato peel powders. Foods 2021, 10, 230. [CrossRef] [PubMed]

17. Saccoliti, F.; Madia, V.N.; Tudino, V.; De Leo, A.; Pescatori, L.; Messore, A.; De Vita, D.; Scipione, L.; Brun, R.; Kaiser, M.; et al. Biological evaluation and structure-activity relationships of imidazole-based compounds as antiprotozoal agents. Eur. J. Med. Chem. 2018, 156, 53-60. [CrossRef] [PubMed]

18. Agarwal, S.; Sharma, V.; Kaul, T.; Abdin, M.Z.; Singh, S. Cytotoxic effect of carotenoid phytonutrient lycopene on P. falciparum infected erythrocytes. Mol. Biochem. Parasitol 2014, 197, 15-20. [CrossRef] [PubMed] 
19. Saccoliti, F.; Madia, V.N.; Tudino, V.; De Leo, A.; Pescatori, L.; Messore, A.; De Vita, D.; Scipione, L.; Brun, R.; Kaiser, M.; et al. Design, synthesis, and biological evaluation of new 1-(aryl-1H-pyrrolyl)(phenyl)methyl- $1 H$-imidazole derivatives as antiprotozoal agents. J. Med. Chem. 2019, 62, 1330-1347. [CrossRef]

20. Seren, S.; Mutchnick, M.; Hutchinson, D.; Harmanci, O.; Bayraktar, Y.; Mutchnick, S.; Sahin, K.; Kucuk, O. Potential role of lycopene in the treatment of hepatitis $C$ and prevention of hepatocellular carcinoma. Nutr. Cancer 2008, 60, 729-735. [CrossRef]

21. Petyaev, I.M. Lycopene deficiency in ageing and cardiovascular disease. Oxid. Med. Cell Longev. 2016, 2016, 3218605. [CrossRef] [PubMed]

22. Agarwal, S.; Rao, A.V. Tomato lycopene and its role in human health and chronic diseases. Can. Med. Assoc. J. 2000, 163, 739-744.

23. Tasca, K.I.; Caleffi, J.T.; Correa, C.R.; Gatto, M.; Tavares, F.C.; Camargo, C.C.; Sartori, A.; Biasin, M.; de Souza, L.D.R. Antiretroviral therapy initiation alters the redox system of asymptomatic HIV-infected individuals: A longitudinal study. Oxid. Med. Cell Longev. 2017, 2017, 9834803. [CrossRef]

24. Cuzzucoli Crucitti, G.; Pescatori, L.; Messore, A.; Madia, V.N.; Pupo, G.; Saccoliti, F.; Scipione, L.; Tortorella, S.; Di Leva, F.S.; Cosconati, S.; et al. Discovery of N-aryl-naphthylamines as in vitro inhibitors of the interaction between HIV integrase and the cofactor LEDGF/p75. Eur. J. Med. Chem. 2015, 101, 288-294. [CrossRef] [PubMed]

25. Coodley, G.O.; Coodley, M.K.; Nelson, H.D. Micro-nutrients in HIV infected women. J. Womens Health 1995, 4, 303-311. [CrossRef]

26. Varma, S.; Karwe, M.V.; Lee, T.-C. Effect of high hydrostatic pressure processing on lycopene isomers. Int. J. Food Eng. 2010, 6. [CrossRef]

27. Lambelet, P.; Richelle, M.; Bortlik, K.; Franceschi, F.; Giori, A.M. Improving the stability of lycopene Z-isomers in isomerised tomato extracts. Food Chem. 2009, 112, 156-161. [CrossRef]

28. Gómez-Prieto, M.S.; Caja, M.M.; Herraiz, M.; Santa-María, G. Supercritical fluid extraction of all-trans-lycopene from tomato. J. Agric. Food Chem. 2003, 51, 3-7. [CrossRef]

29. Chen, J.; Shi, J.; Xue, S.J.; Ma, Y. Comparison of lycopene stability in water- and oil-based food model systems under thermal- and light-irradiation treatments. LWT-Food Sci. Technol. 2009, 42, 740-747. [CrossRef]

30. Shi, J.; Dai, Y.; Kakuda, Y.; Mittal, G.; Xue, S.J. Effect of heating and exposure to light on the stability of lycopene in tomato purée. Food Control. 2008, 19, 514-520. [CrossRef]

31. Honest, K.N.; Zhang, H.W.; Zhang, L. Lycopene: Isomerization effects on bioavailability and bioactivity properties. Food Rev. Int. 2011, 27, 248-258. [CrossRef]

32. Arballo, J.; Amengual, J.; Erdman, J.W., Jr. Lycopene: A critical review of digestion, absorption, metabolism, and excretion. Antioxidants 2021, 10, 342. [CrossRef] [PubMed]

33. Shi, J.; Le Maguer, M. Lycopene in tomatoes: Chemical and physical properties affected by food processing. Crit. Rev. Biotechnol. 2000, 20, 293-334. [CrossRef]

34. Hussein, L.; el-Tohamy, M. Vitamin A potency of carrot and spinach carotenes in human metabolic studies. Int. J. Vitam. Nutr. Res. 1990, 60, 229-235. [PubMed]

35. Khaw, K.Y.; Parat, M.O.; Shaw, P.N.; Falconer, J.R. Solvent supercritical fluid technologies to extract bioactive compounds from natural sources: A review. Molecules 2017, 22, 1186. [CrossRef]

36. Mai, A.A.; Al Dajah, S.; Murad, A.A.; El-Salem, A.M.; Khafajah, A.M. Extraction, purification, and characterization of lycopene from jordanian vine tomato cultivar, and study of its potential natural antioxidant effect on Samen Baladi. Curr. Res. Nutr. Food Sci. 2019, 7, 532. [CrossRef]

37. Pandya, D.; Akbari, S.; Bhatt, H.; Joshi, D.; Darji, V. Standardization of solvent extraction process for Lycopene extraction from tomato pomace. J. Appl. Biotechnol. Bioeng. 2017, 2, 00019. [CrossRef]

38. Strati, I.F.; Oreopoulou, V. Recovery of carotenoids from tomato processing by-products-A review. Food Res. Int. 2014, 65, 311-321. [CrossRef]

39. Zuorro, A. Enhanced lycopene extraction from tomato peels by optimized mixed-polarity solvent mixtures. Molecules 2020, 25, 2038. [CrossRef] [PubMed]

40. Lynge, E.; Anttila, A.; Hemminki, K. Organic solvents and cancer. Cancer Causes Control. 1997, 8, 406-419. [CrossRef]

41. McLaughlin, J.K.; Lipworth, L. Epidemiologic aspects of renal cell cancer. Semin. Oncol. 2000, 27, 115-123.

42. Dick, F.D. Solvent neurotoxicity. Occup. Environ. Med. 2006, 63, 221-226. [CrossRef]

43. Buchmann, L.; Mathys, A. perspective on pulsed electric field treatment in the bio-based industry. Front. Bioeng. Biotechnol. 2019, 7, 265. [CrossRef] [PubMed]

44. Luengo, E.; Condón-Abanto, S.; Condón, S.; Álvarez, I.; Raso, J. Improving the extraction of carotenoids from tomato waste by application of ultrasound under pressure. Sep. Purif. Technol. 2014, 136, 130-136. [CrossRef]

45. Shree, T.J.; Sree, V.G.; Nagaraj, S. Effect of pulsed electric field on lycopene extraction. Int. J. Circuit Theory Appl. 2016, 9, 7345-7350.

46. Pataro, G.; Carullo, D.; Ferrari, G. Effect of PEF pre-treatment and extraction temperature on the recovery of carotenoids from tomato wastes. Chem. Eng. Trans. 2019, 75. [CrossRef]

47. Pataro, G.; Carullo, D.; Falcone, M.; Ferrari, G. Recovery of lycopene from industrially derived tomato processing by-products by pulsed electric fields-assisted extraction. Innov. Food Sci. Emerg. Technol. 2020, 102369. [CrossRef]

48. Andreou, V.; Dimopoulos, G.; Dermesonlouoglou, E.; Taoukis, P. Application of pulsed electric fields to improve product yield and waste valorization in industrial tomato processing. J. Food Eng. 2020, 270, 109778. [CrossRef] 
49. Puri, M.; Sharma, D.; Barrow, C.J. Enzyme-assisted extraction of bioactives from plants. Trends Biotechnol. 2012 , 30, 37-44. [CrossRef] [PubMed]

50. Choudhari, S.M.; Ananthanarayan, L. Enzyme aided extraction of lycopene from tomato tissues. Food Chem. 2007, 102, 77-81. [CrossRef]

51. Ranveer, R.C.; Patil, S.N.; Sahoo, A.K. Effect of different parameters on enzyme-assisted extraction of lycopene from tomato processing waste. Food Bioprod. Process. 2013, 91, 370-375. [CrossRef]

52. Munde, P.J.; Muley, A.B.; Ladole, M.R.; Pawar, A.V.; Talib, M.I.; Parate, V.R. Optimization of pectinase-assisted and tri-solventmediated extraction and recovery of lycopene from waste tomato peels. 3 Biotech 2017, 7, 206. [CrossRef]

53. Prokopov, T.; Nikolova, M.; Dobrev, G.; Taneva, D. Enzyme-assisted extraction of carotenoids from Bulgarian tomato peels. Acta Aliment. 2017, 46, 84-91. [CrossRef]

54. Catalkaya, G.; Kahveci, D. Optimization of enzyme assisted extraction of lycopene from industrial tomato waste. Sep. Purif. Technol. 2019, 2019, 55-63. [CrossRef]

55. Lavecchia, R.; Zuorro, A. Improved lycopene extraction from tomato peels using cell-wall degrading enzymes. Eur. Food Res. Technol. 2008, 228, 153. [CrossRef]

56. Zuorro, A.; Fidaleo, M.; Lavecchia, R. Enzyme-assisted extraction of lycopene from tomato processing waste. Enzym. Microb. Technol. 2011, 6, 567-573. [CrossRef] [PubMed]

57. Lombardelli, C.; Liburdi, K.; Benucci, I.; Esti, M. Tailored and synergistic enzyme-assisted extraction of carotenoid-containing chromoplasts from tomatoes. Food Bioprod. Process. 2020, 121, 43-53. [CrossRef]

58. Cuccolini, S.; Aldini, A.; Visai, L.; Daglia, M.; Ferrari, D. Environmentally friendly lycopene purification from tomato peel waste: Enzymatic assisted aqueous extraction. J. Agric. Food Chem. 2013, 61, 1646-1651. [CrossRef] [PubMed]

59. Shi, J.; Jun Xue, S.; Jiang, Y.; Ye, X. 20-Supercritical-fluid extraction of lycopene from tomatoes. Sep. Extr. Conc. Process. Food Beverage Nutraceutical Ind. Woodhead Publ. 2013, 619-645.e646. [CrossRef]

60. Pellicano, T.M.; Sicari, V.; Loizzo, M.R.; Leporini, M.; Falco, T.; Poiana., M. Optimizing the supercritical fluid extraction process of bioactive compounds from processed tomato skin by-products. Food Sci. Technol. 2020, 40, 692-697. [CrossRef]

61. Madia, V.N.; De Angelis, M.; De Vita, D.; Messore, A.; De Leo, A.; Ialongo, D.; Tudino, V.; Saccoliti, F.; De Chiara, G.; Garzoli, S.; et al. Investigation of Commiphora myrrha (Nees) Engl. Oil and Its Main Components for Antiviral Activity. Pharmaceuticals 2021, 14, 243. [CrossRef] [PubMed]

62. De Vita, D.; Messore, A.; Toniolo, C.; Frezza, C.; Scipione, L.; Bertea, C.M.; Micera, M.; Di Sarno, V.; Madia, V.N.; Pindinello, I.; et al. Towards a new application of amaranth seed oil as an agent against Candida albicans. Nat. Prod. Res. 2019, 4, 1-6. [CrossRef]

63. Kehili, M.; Kammlott, M.; Choura, S.; Zammel, A.; Zetzl, C.; Smirnova, I.; Allouche, N.; Sayadi, S. Supercritical CO 2 extraction and antioxidant activity of lycopene and $\beta$-carotene-enriched oleoresin from tomato (Lycopersicum esculentum L.) peels by-product of a Tunisian industry. Food Bioprod. Process. 2017, 102, 340-349. [CrossRef]

64. Rozzi, N.L.; Singh, R.K.; Vierling, R.A.; Watkins, B.A. Supercritical fluid extraction of lycopene from tomato processing byproducts. J. Agric. Food Chem. 2002, 50, 2638-2643. [CrossRef]

65. Topal, U.; Sasaki, M.; Goto, M.; Hayakawa, K. Extraction of lycopene from tomato skin with supercritical carbon dioxide: Effect of operating conditions and solubility analysis. J. Agric. Food Chem. 2006, 54, 5604-5610. [CrossRef] [PubMed]

66. Mayeaux, M.; Xu, Z.; King, J.M.; Prinyawiwatkul, W. Effects of cooking conditions on the lycopene content in tomatoes. J. Food Sci. 2006, 71, 461-464. [CrossRef]

67. Vági, E.; Simándi, B.; Vásárhelyiné, K.; Daood, H.; Kéry, Á.; Doleschall, F.; Nagy, B. Supercritical carbon dioxide extraction of carotenoids, tocopherols and sitosterols from industrial tomato by-products. J. Supercrit. Fluids 2007, 40, 218-226. [CrossRef]

68. Zhang, K.S.; Jiang, H.; Ren, Y.X. The effect of technical parameters on lycopene extraction in supercritical fluid extraction from freeze-dried tomato pomace (peels and seeds). Adv. Mater. Res. 2011, 236, 2868-2871. [CrossRef]

69. Baysal, T.; Ersus, S.; Starmans, J.D.A. Supercritical $\mathrm{CO}_{2}$ extraction of b-carotene and lycopene from tomato paste waste. J. Agric. Food Chem. 2000, 48, 5507-5511. [CrossRef]

70. Huang, W.; Li, Z.; Niu, H.; Li, D.; Zhang, J. Optimization of operating parameters for supercritical carbon dioxide extraction of lycopene by response surface methodology. J. Food Eng. 2008, 89, 298-302. [CrossRef]

71. Shi, J.; Yi, C.; Xue, J.; Jiang, Y.; Ma, Y.; Li, D. Effects of modifier on lycopene extract profile from tomato skin using supercritical-CO 2 fluid. J. Food Eng 2009, 93, 431-436. [CrossRef]

72. Yi, C.; Shi, J.; Xue, J.; Jiang, Y.; Li, D. Effects of supercritical fluid extraction parameters on lycopene yield and antioxidant activity. Food Chem. 2009, 113, 1088-1094. [CrossRef]

73. Margotta, M.; Simone, M.C.D. Supercritical Fluid Extraction of Lycopene and Omega-3. New Technol., Dev. Appl. III 2020, 128, 750-758. [CrossRef]

74. Perretti, G.; Troilo, A.; Bravi, E.; Marconi, O.; Galgano, F.; Fantozzi, P. Production of a lycopene-enriched fraction from tomato pomace using supercritical carbon dioxide. J. Supercrit. Fluids 2013, 82, 177-182. [CrossRef]

75. Machmudah, S.; Winardi, S.; Sasaki, M.; Goto, M.; Kusumoto, N.; Hayakawa, K. Lycopene extraction from tomato peel by-product containing tomato seed using supercritical carbon dioxide. J. Food Eng. 2012, 108, 290-296. [CrossRef]

76. Mayer-Miebach, E.; Behsnilian, D.; Regier, M.; Schuchmann, H.P. Thermal processing of carrots: Lycopene stability and isomerisation with regard to antioxidant potential. Food Res. Int. 2005, 38, 1103-1108. [CrossRef] 
77. Mason, T.J.; Lorimer, J.P. Applied Sonochemistry: Uses of Power Ultrasound in Chemistry and Processing, 1st ed.; Wiley-VCH: Weeinheim, Germany, 2002; pp. 1-24. [CrossRef]

78. Patist, A.; Bates, D. Ultrasonic innovations in the food industry: From the laboratory to commercial product. Innov. Food Sci. Emerg. 2008, 9, 147-154. [CrossRef]

79. Soria, A.C.; Villamiel, M. Effect of ultrasound on the technological properties, bioactivity of food: A review. Trends Food Sci. Technol. 2010, 21, 323-331. [CrossRef]

80. Toma, M.; Vinatoru, M.; Paniwnyk, L.; Mason, T.J. Investigation of the effects of ultrasound on vegetal tissues during solvent extraction. Ultrason. Sonochem. 2001, 8, 137-142. [CrossRef]

81. Vinatoru, M. An overview of the ultrasonically assisted extraction of bioactive principles from herbs. Ultrason. Sonochem. 2001, 8, 303-313. [CrossRef]

82. Wang, J.; Sun, B.; Cao, Y.; Tian, Y.; Li, X. Optimisation of ultrasound-assisted extraction of phenolic compounds from wheat bran. Food Chem. 2008, 106, 804-810. [CrossRef]

83. Khan, M.K.; Vian, M.A.; Tixier, S.F.; Dangles, O.; Chemat, F. Ultrasound-assisted extraction of polyphenols (flavanone glycosides) from orange (Citrus sinensis L.) peel. Food Chem. 2010, 119, 851-858. [CrossRef]

84. Sivakumar, V.; Anna, J.L.; Vijayeeswarri, J.; Swaminathan, G. Ultrasound assisted enhancement in natural dye extraction from beetroot for industrial applications and natural dyeing of leather. Ultrason. Sonochem. 2009, 16, 782-789. [CrossRef] [PubMed]

85. $\mathrm{Xu}, \mathrm{Z}$. Comparison of extraction methods for quantifying vitamin E from animal tissues. Bioresour. Technol. 2008, 99, 8705-8709. [CrossRef]

86. Yilmaz, T.; Kumcuoglu, S.; Tavman, S. Ultrasound assisted extraction of lycopene and $\beta$-carotene from tomato processing wastes. Ital. J. Food Sci. 2017, 29, 186-194. [CrossRef]

87. Sun, Y.; Liu, D.; Chen, J.; Ye, X.; Yu, D. Effects of different factors of ultrasound treatment on the extraction yield of the all-trans- $\beta$-carotene from citrus peels. Ultrason. Sonochem. 2011, 18, 243-249. [CrossRef] [PubMed]

88. Kumcuoglu, S.; Yilmaz, T.; Tavman, S. Ultrasound assisted extraction of lycopene from tomato processing wastes. J. Food Sci. Technol. 2014, 51, 4102-4107. [CrossRef] [PubMed]

89. Xu, Y.; Pan, S. Effects of various factors of ultrasonic treatment on the extraction yield of all-trans-lycopene from red grapefruit (Citrus paradise Macf. ). Ultrason. Sonochem. 2013, 20, 1026-1032. [CrossRef] [PubMed]

90. Wang, L.; Weller, C.L. Recent advances in extraction of nutraceuticals from plants. Trends Food Sci. Technol. 2006, 17, 300-312. [CrossRef]

91. Jerman, T.; Trebše, P.; Mozetič Vodopivec, B. Ultrasound-assisted solid liquid extraction (USLE) of olive fruit (Olea europaea) phenolic compounds. Food Chem. 2010, 123, 175-182. [CrossRef]

92. Sun, Y.; Ma, G.; Ye, X.; Kakuda, Y.; Meng, R. Stability of all-trans-beta-carotene under ultrasound treatment in a model system: Effects of different factors, kinetics and newly formed compounds. Ultrason. Sonochem. 2010, 17, 654-661. [CrossRef]

93. Lianfu, Z.; Zelong, L. Optimization and comparison of ultrasound/microwave assisted extraction (UMAE) and ultrasonic assisted extraction (UAE) of lycopene from tomatoes. Ultrason. Sonochem. 2008, 15, 731-737. [CrossRef]

94. Adekunte, A.O.; Tiwari, B.K.; Cullen, P.J.; Scannell, A.G.M.; O'Donnell, C.P. Effect of sonication on colour, ascorbic acid and yeast inactivation in tomato juice. Food Chem. 2010, 122, 500-507. [CrossRef]

95. Amiri-Rigi, A.; Abbasi, S.; Scanlon, M.G. Enhanced lycopene extraction from tomato industrial waste using microemulsion technique: Optimization of enzymatic and ultrasound pre-treatments. Innov. Food Sci. Emerg. Technol. 2016, 35, 160-167. [CrossRef]

96. Paduano, A.; Caporaso, N.; Santini, A.; Sacchi, R. Microwave and ultrasound-assisted extraction of capsaicinoids from chili peppers (Capsicum annuum L.) in flavored olive oil. J. Food Res. 2014, 3, 51-59. [CrossRef]

97. De Vita, D.; Madia, V.N.; Tudino, V.; Saccoliti, F.; De Leo, A.; Messore, A.; Roscilli, P.; Botto, A.; Pindinello, I.; Santilli, G.; et al. Comparison of different methods for the extraction of cannabinoids from cannabis. Nat. Prod. Res. 2020, 34, 2952-2958. [CrossRef]

98. Chaturvedi, A.K. Extraction of nutraceuticals from plants by microwave assisted extraction. Syst. Rev. Pharm. 2018, 9, 31-35. [CrossRef]

99. Angiolillo, L.; Del Nobile, M.A.; Conte, A. The extraction of bioactive compounds from food residues using microwaves. Curr. Opin. Food Sci. 2015, 5, 93-98. [CrossRef]

100. Moret, S.; Conchione, C.; Srbinovska, A.; Lucci, P. Microwave-based technique for fast and reliable extraction of organic contaminants from food, with a special focus on hydrocarbon contaminants. Foods 2019, 8, 503. [CrossRef]

101. Delazar, A.; Nahar, L.; Hamedeyazdan, S.; Sarker, S.D. Microwave-assisted extraction in natural products isolation. Methods Mol. Biol. 2012, 864, 89-115. [CrossRef]

102. Ganzler, K.; Salgó, A.; Valkó, K. Microwave extraction: A novel sample preparation method for chromatography. J. Chromatogr. A 1986, 371, 299-306. [CrossRef]

103. Routray, W.; Orsat, V. Microwave-assisted extraction of flavonoids: A review. Food Bioprocess. Technol. 2012, 5, 409-424. [CrossRef]

104. Mandal, V.; Mohan, Y.; Hemalatha, S. Microwave-assisted extraction-an innovative and promising extraction tool for medicinal plant research. Pharmacogn. Rev. 2007, 1,7-18.

105. Ho, K.K.H.Y.; Ferruzzi, M.G.; Liceaga, A.M.; San Martín-Gonzalez, M.F. Microwave-assisted extraction of lycopene in tomato peels: Effect of extraction conditions on all-trans and cis-isomer yields. LWT-Food Sci. Technol. 2015, 62, 160-168. [CrossRef] 
106. Materna, K.; Szymanowski, J. Separation of phenols from aqueous micellar solutions by cloud point extraction. J. Colloid Interface Sci. 2002, 255, 195-201. [CrossRef] [PubMed]

107. Abbasi, S.; Radi, M. Food grade microemulsion systems: Canola oil/lecithin: N-propanol/water. Food Chem. 2016, 194, 972-979. [CrossRef] [PubMed]

108. Radi, M.; Abbasi, S.; Hamidi-Esfahani, Z.; Azizi, M.H. Development of a new method for extraction of canola oil using lecithin based microemulsion systems. Agro Food Ind. Hi-Tech 2013, 24, 70-72.

109. Ugolini, L.; DeNicola, G.; Palmieri, S. Use of reverse micelles for the simultaneous extraction of oil, proteins, and glucosinolates from Cruciferous oilseeds. J. Agric. Food Chem. 2008, 56, 1595-1601. [CrossRef] [PubMed]

110. Amiri-Rigi, A.; Abbasi, S. Extraction of lycopene using a lecithin-based olive oil microemulsion. Food Chem. 2019, 272, 568-573. [CrossRef]

111. Patel, N.; Schmid, U.; Lawrence, M.J. Phospholipid-based microemulsions suitable for use in foods. J. Agric. Food Chem. 2006, 54, 7817-7824. [CrossRef]

112. Amiri-Rigi, A.; Abbasi, S. Microemulsion-based lycopene extraction: Effect of surfactants, co-surfactants and pretreatments Food Chem. 2016, 197 Pt A, 1002-1007. [CrossRef] [PubMed]

113. Abdelkader, M.B.; Azizi, N.; Chemli, M.; Chevalier, Y.; Boyron, O.; Majdoub, M. Synthesis and emulsifier properties of a new bio-sourced surfactant based on isosorbide. Colloids Surf. A Physicochem. Eng. Asp. 2016, 492, 1-11. [CrossRef]

114. Nagarajan, J.; Pui Kay, H.; Krishnamurthy, N.P.; Ramakrishnan, N.R.; Aldawoud, T.M.S.; Galanakis, C.M.; Wei, O.C. Ex-traction of carotenoids from tomato pomace via water-induced hydrocolloidal complexation. Biomolecules 2020, 10, 1019. [CrossRef] 